\title{
A Litany of Queer Anger
}

Response to Presidential Address

Adam J. Greteman

School of the Art Institute of Chicago

For Cris Mayo there is a need to pause and check anger's cause, to follow anger through and, in doing so, redeem anger for what it teaches about our everydayness. Mayo's project is at its heart, in my reading, a redemptive project. Anger has potential and needs another chance to show its educative value. Anger is not only for itself, but for others. For my response, I want to contemplate an echo of queer anger, its educative potential, and its limitations. I'll do this by returning to Queers Read This, a militant queer pamphlet that was anonymously published by queers and distributed at the 1990 Pride March in New York City. Throughout it, various anonymous "queer I's" write of anger. This anger - refracted through hatred - is directed at any number of prominent homophobic figures of the time period like Jesse Helms and Cardinal John J. O'Connor, institutions like the Catholic church and Medical establishment along with, quite generally, heterosexuality. ${ }^{1}$ Of particular interest to me is the hatred and anger directed at education, as an institution and a profession, and if or how, decades later, education has learned any lessons from this anonymous queer anger.

\section{A RETURN}

In returning to Queers Read This thirty years after its publication and distribution, I read it as a litany of queer anger that provides me and perhaps us, with a way to touch a queer past and what it transmits through its repetition of anger into our contemporary context. Queers Read petitions its readers to listen and to hear the raging prayers of the sacrificial lambs of an imagined "Christian nation" who were and still 
are being led to the slaughter.

Anger, as expressed on the broadsheets and streets of the slow mainstreaming of "gay" liberation, now provides us with ways to glimpse how queer anger expanded (momentarily) the intelligibility of queer anger then to transform sexual ethics now under threat again. For Marilyn Frye a key purpose in using anger politically is to expand anger's intelligibility so that such anger is taken up by others. As she argued in "A Note on Anger,"

To expand the scope of one's intelligible anger is to change one's place in the universe, to change another's concept of what one is, to become something different in that social and collective scheme which determines the limits of the intelligible. $^{2}$

Looking backwards, we can see the methodical work of queer anger as it sought to intercede and intervene in the homophobic, racist, misogynist world being laid bare by the AIDS epidemic. Queers became something different as they used anger and its performance to alter the landscape for the survivors and eventual inheritors of queerness. Yet, for some, queer difference became a certain indifference on the road to respectability.

Yet, those angers expressed through different anonymous I's were effective. The anger of anonymous queers, layered on top of activisms of the time, shifted the view that many had of HIV/ AIDS and transformed the world by expanding medical trials, getting drugs into bodies, humanizing People with AIDS, and much more. Yet such shifts were short-lived, as access to drugs and a standard of care by and large benefited those with various forms of privilege. Queer 
anger was taken up in the streets, until it wasn't, replaced by suits seeking access to traditional institutions previously hated. The anger of Queers Read This would give way, in part, to respectable gay rights and a move away from gay liberation's radical visions. ${ }^{3}$

Yet, there in the archives of "queer" exist glimmers of anger and its methods. Thirty years later, the anger of Queers Read This returns to intervene in not just our heteronormative world, but our homonormative world as well. Thirty years ago, Queers Read This may very well have been read as a manifesto. However, today it is a litany that petitions those of us who have inherited such queer lineage to intercede on the behalf of our queer saints sacrificed at the altar of pharmaceutical greed, respectability politics, governmental neglect, and important for us here, educational malfeasance.

Education is one of the key institutions that angered the anonymous queers. The anonymous I wrote, amidst a litany of hate:

I hate that in twelve years of public education I was never taught about queer people. I hate that I grew up thinking I was the only queer in the world, and I hate even more that most queer kids still grow up the same way. I hate that I was tormented by other kids for being a faggot, but more that I was taught to feel ashamed for being the object of their cruelty, taught to feel it was my fault. ${ }^{4}$

Contemporary research shows that these realities have budged very little. LGBTQ youth still have higher than average suicide rates for teenagers, more states in the US have "no-promo homo" laws than do states requiring LGBTQ history be taught, and teachers can still be fired for being gay. Hatred in the hallways and classrooms is still persistent despite efforts at making LGBTQ issues respectable. Schools have, often because of litigation, made a place in the school 
for queers. Yet such spaces do not disrupt the educational project. Rather, LGBTQ students are in some forms welcomed into the fold, welcomed conditionally if they accept the school traditions as they are.

This should justifiably make education professionals angry. After all, if you're not angry, you're not paying attention, so the saying goes. Yet, for some the very idea of including LGBTQ students and teachers - much less topics - provokes what those opposed to such inclusion see as their own justifiable anger. Others still feel there are more pressing issues to be angry about since sexuality and gender identity are "merely cultural." Perhaps, with such diverse angers it is not the anger that matters, but that we are paying attention. And in paying attention are able to attend to the different ways anger is used. "Anger is," as Mayo argues, "an amplification of the desire that another pay attention to a problem they are ignoring." 5 And I suspect in our own positions we desire others to attend to particular problems in our purview, but are perhaps less willing to attend to the desires of those others with whom we disagree. "Easier, perhaps," Mayo suggests, “to be angry than to see that other people have good reason to be angry themselves." ${ }^{\circ}$ Everyone seems able and ready to express anger, so, as Mayo notes, "understanding our own various angers better may give us a method for understanding the anger of others too." " Understanding anger is, it would appear, more central to the educational uses of anger than provoking anger as an educational value.

I worry, however, in spite of the move toward understanding, that anger, as it is felt and used politically, has become ubiquitous and has lost its righteousness. After all, Marilyn Frye argued "anger is always righteous." "To be angry," she continued, "you have to have some sense of the rightness or propriety of your position and your interest in whatever has been hindered, interfered with or harmed and 
anger implies a claim to such righteousness or propriety."' If anger is ubiquitous and if everyone is angry, how do we gain a sense of rightness? I worry myself that I suffer too greatly from the imposter syndrome to be able to assert "rightness," and as a queer, "propriety" has never been my forte. The very idea of such an assertion of rightness causes me a certain level of anxiety, causing me to ask perhaps if I'm wrong, perhaps I am missing something, perhaps I wasn't paying proper attention, perhaps I've nothing to be angry about. Perhaps this is why I myself avoid anger in favor of anxiety, which Avital Ronnel argues is "the mood of ethicity."

\section{CONCLUDE}

Let me move to a conclusion. The everyday reality that anger is everywhere in various forms, exposes for me the "feel goodness" and limitations of the pithy statement "If you're not angry, you're not paying attention.” In our current conditions of anger's ubiquity, anger may distract us more than it informs us. Its assertion both fails to grapple with the multiple, competing and contradictory ways in which attention might be paid through anger and fails to question if anger is the best emotion for our attentiveness. The rhetorical persuasiveness of the statement outpaces the realities of feeling anger; anger does not always emerge from, nor provide, a clear mind. Nor do I think anger is always right. The clarity of anger comes, it seems, after the fact hours, days, years, perhaps decades later when we are able to work with and through our anger or questions raised of it. Anger's righteousness may be methodically birthed once we have seen its consequences.

Returning to Queers Read This we can hear anger echoing through the decades, righteously pointing out the courageous efforts of queers amidst an epidemic. The different anonymous I's, when combined, provide a comprehensive litany of anger. Queer anger 
cannot be monolithic as it encounters its own desires and ignorances as different queers from different positions encounter different realities. Yet, to encounter such queer anger feels right to me educationally. As a queer philosopher of education, I was never taught about queer people, much like the anonymous I's of Queers Read This. And I know students still enter the classroom having never been taught about queer people. They do perhaps know more queer people, but they've yet to have a queer education that ushers them into cultural histories, herstories, and hirstories. Realizing this lack, they often express anger and, in doing so, start paying attention.

1 Anonymous Queers, Queers Read This (1990/2016), http://www.qrd.org/qrd/misc/ text/queers.read.this

2 Marilyn Frye, "A Note on Anger" in The Politics of Reality (Trumansburg, NY: The Crossinng Press, 1983), 92.

3 Martin Duberman, Has the Gay Movement Failed? (Oakland, CA: University of California Press, 2018).

4 Anonymous Queers, Queers Read This, 8.

5 Cris Mayo, “Teaching Anger” Philosophy of Education 2020, 15.

6 Mayo, “Teaching Anger,” 15.

7 Mayo, “Teaching Anger," 15.

8 Frye, "Notes on Anger," 86.

9 Frye, "Notes on Anger," 86.

10 Examined Life, directed by Astra Taylor (2008; Toronto, Canada: Sphinx Productions, 2009), DVD. 
DoI: $10.47925 / 76.1 .028$ 